International Journal of Child, Youth and Family Studies (2014) 5(2): 220-239

\title{
SOCIAL DETERMINANTS OF CHILDREN'S HEALTH IN CANADA: ANALYSIS AND IMPLICATIONS ${ }^{1}$
}

\section{Dennis Raphael}

\begin{abstract}
The health of Canada's children when placed in comparative perspective with other wealthy developed nations is mediocre at best. Much of this has to do with the social determinants of children's health (SDCH) in Canada being of generally lower quality and more inequitably distributed than is the case in most other wealthy developed nations. The SDCH are of two kinds: (a) those to which their parents are exposed, and (b) those specifically related to societal support for early child development. In both cases Canada's support of the SDCH through the making of health promoting public policy is lacking. Much of this has to do with the political ideology of ruling governments consistent with Canada being identified as a liberal welfare state where intervention in the unbridled operation of the market system is frowned upon. There are means of improving the situation. These involve a wide range of activities from more responsive clinical practice through to advocacy and political action.
\end{abstract}

Keywords: social determinants, public policy, political economy of health

Dennis Raphael, Ph.D. is Professor of Health Policy and Management at York University, Room 418, HNES Building, 4700 Keele Street, Toronto, Ontario, Canada, M3J 1P3.

E-mail: draphael@yorku.ca.

\footnotetext{
${ }^{1}$ Material in this paper was presented at the symposium The Coming of Age of Social Paediatrics, a Symposium cosponsored by the Canadian Child and Youth Health Coalition and Paediatric Chairs of Canada, Toronto, October 20, 2013.
} 
International Journal of Child, Youth and Family Studies (2014) 5(2): 220-239

In this article I consider the current state of the social determinants of children's health $(\mathrm{SDCH})$ in Canada. After briefly describing how Canadian children's physical, mental, and social health compares to children in other wealthy developed countries (Canada's performance is mediocre at best), I explore how children's health is related to the quality and distribution of a variety of SDCH in Canada. Here again, Canada's performance as compared to other wealthy developed nations is not exemplary.

I then examine the determinants of the SDCH in Canada. This involves an exploration of how public policy in Canada shapes the quality and distribution of the SDCH to which Canadian children are exposed. It is suggested that much of what passes for public policy in Canada can be explained by recourse to Canada being a liberal welfare state in which State intervention in the operation of the market economy through enactment of employment standards, laws, and the provision of universal supports and benefits to families with children is minimal. The resurgence of the ideology of neo-liberalism over the past 25 years has only reinforced these Canadian public policy trends.

Canada's modest expenditures on benefits, programs, and services that would improve the quality and distribution of the SDCH can be explained by politics in that the political ideology of governing authorities at the federal, provincial, and municipal levels shape these public policy approaches. These policies continue because the public has not been presented with an alternative to the neo-liberal welfare state where governments do little to promote children's health through action in SDCH-related public policy areas.

Complicating this situation is the existence of a variety of research and professional discourses by which the SDCH are understood. These range from seeing the SDCH as identifying those in need of health and social services through to one that identifies those sectors of society that benefit from children being exposed to health-threatening SDCH. The article concludes by outlining various means by which the SDCH could be improved. It is argued that what is really necessary is the strengthening of the environments in which children and their parents live, work, and play through the creation of healthy public policy that improves the quality and distribution of the SDCH. Whether this can occur without profound political change that involves the shifting of power and influence in Canadian society remains an open question.

\section{The State of Children's Health in Canada}

Children's health is important as it serves as a foundation for health across the lifespan (Hertzman \& Power, 2003; Irwin, Siddiqui, \& Hertzman, 2007; Kuh, Ben Shlomo, \& Susser, 2004). A number of recent special publications have surveyed the state of children's health in Canada and have found Canada's approach to supporting children's health generally wanting (Haddad, 2010, 2011a, 2011b, 2012; Raphael, 2010a, 2010b, 2010c; Raphael, 2010d). Since there is no central Canadian agency responsible for monitoring the health of Canadians in general and children's health in particular, it is left to numerous independent researchers in universities and research institutes to provide information on the state of children's health and the SDCH (Raphael, 2012a). These data are difficult to interpret without benefit of comparative analysis that takes into account the situation of children in other wealthy developed nations. 
Fortunately, UNICEF’s Innocenti Research Centre in Florence, Italy provides ongoing comparative analysis of children's situations across wealthy developed nations that move beyond simple presentation of comparative data to careful analysis of the public policy antecedents that shape children's health in these nations. Much of their data is taken from work done by the Organisation for Economic Cooperation and Development (Organisation for Economic Cooperation and Development, 2011a, 2011b).

\section{Infant Mortality and Low Birth Weight Rates}

Two key indicators of children’s health are infant mortality and low birth weight rates. Infant mortality rate is seen as an especially sensitive indicator of the overall health of a population that is shaped by the quality and distribution of the SDCH (Butler-Jones, 2008). The figures for Canada are rather striking. In addition to Canada having one of the highest infant mortality rates among wealthy developed nations, of special importance is the shift in relative ranking of Canada since 1980. In 1980 Canada ranked 10th in infant mortality rates of 24 OECD nations (Robert Wood Johnson Foundation, 2008). But by 2010 Canada's ranking had slipped to 27th of 36 nations (Organisation for Economic Co-operation and Development, 2011a). Canada's comparative performance for low birth weight rate - a good predictor of health during childhood and adulthood - is somewhat better. Canada currently ranks 11th of 29 OECD nations on this indicator (Organisation for Economic Co-operation and Development, 2011a). Earlier Innocenti reports provide a rather poor portrait of Canada's standings on other health indicators such as teen pregnancies, mortality from injuries, and mortality from parental abuse (Innocenti Research Centre, 2001a, 2001b, 2003).

\section{Canadian Children's Well-being in International Perspective}

The Innocenti Research Centre’s 2013 Report Card examined children’s well-being along five dimensions: material well-being, health and safety, education, behaviours and risks, and housing and environment (Innocenti Research Centre, 2013). Canada's overall rank was 17th of 29 wealthy developed nations. It ranks 15th in material well-being, 27th in health and safety, 14th in education, 16th in behaviours and risks, and 11th in housing and environment.

Table 1 provides the contributors to these different dimensions. It is important to note that while the nations whose children fare better than Canada unsurprisingly include the Social Democratic Nordic nations of Norway, Iceland, Finland, Sweden, and Denmark where commitment to children's health is expressed through extensive provision to families of economic and social security, they also include many of the Conservative nations of Continental Europe: the Netherlands, Germany, Luxembourg, Switzerland, Belgium, and France. These findings should be of significant concern. Indeed, UNICEF Canada produced a critical companion report to the Innocenti Report Card on the situation of Canadian children entitled Stuck in the Middle (UNICEF Canada, 2013). 
International Journal of Child, Youth and Family Studies (2014) 5(2): 220-239

\begin{tabular}{|c|c|c|}
\hline Dimensions & Components & Indicators \\
\hline \multirow{4}{*}{$\begin{array}{l}\text { Dimension 1: } \\
\text { Material well-being }\end{array}$} & \multirow{2}{*}{ Monetary deprivation } & Relative child poverty rate \\
\hline & & Relative child poverty gap \\
\hline & \multirow{2}{*}{ Material deprivation } & Child deprivation rate \\
\hline & & Low family affluence rate \\
\hline \multirow{4}{*}{$\begin{array}{l}\text { Dimension 2: } \\
\text { Health and safety }\end{array}$} & \multirow{2}{*}{ Health at birth } & Infant mortality rate \\
\hline & & Low birthweight rate \\
\hline & Preventive health services & Overall immunization rate \\
\hline & Childhood mortality & Child death rate, age 1 to 19 \\
\hline \multirow[t]{4}{*}{$\begin{array}{l}\text { Dimension 3: } \\
\text { Education }\end{array}$} & \multirow{3}{*}{ Participation } & $\begin{array}{l}\text { Participation rate: early childhood } \\
\text { education }\end{array}$ \\
\hline & & $\begin{array}{l}\text { Participation rate: further education, } \\
\text { age } 15-19\end{array}$ \\
\hline & & $\begin{array}{l}\text { NEET rate (\% age } 15-19 \text { not in } \\
\text { education, employment or training) }\end{array}$ \\
\hline & Achievement & $\begin{array}{l}\text { Average PISA scores in reading, } \\
\text { maths and science }\end{array}$ \\
\hline \multirow{9}{*}{$\begin{array}{l}\text { Dimension 4: } \\
\text { Behaviours and risks }\end{array}$} & \multirow{4}{*}{ Health behaviours } & Being overweight \\
\hline & & Eating breakfast \\
\hline & & Eating fruit \\
\hline & & Taking exercise \\
\hline & \multirow{4}{*}{ Risk behaviours } & Teenage fertility rate \\
\hline & & Smoking \\
\hline & & Alcohol \\
\hline & & Cannabis \\
\hline & Exposure to violence & $\begin{array}{l}\text { Fighting } \\
\text { Being bullied }\end{array}$ \\
\hline \multirow{2}{*}{$\begin{array}{l}\text { Dimension 5: } \\
\text { Housing and } \\
\text { environment }\end{array}$} & Housing & $\begin{array}{l}\text { Rooms per person } \\
\text { Multiple housing problems }\end{array}$ \\
\hline & Environmental safety & $\begin{array}{l}\text { Homicide rate } \\
\text { Air pollution }\end{array}$ \\
\hline
\end{tabular}

Source: Innocenti Research Centre (2013). Child Well-being in Rich Countries: A Comparative Overview, Box 1, p. 5. Florence: Innocenti Research Centre. 
International Journal of Child, Youth and Family Studies (2014) 5(2): 220-239

Numerous analyses show these rankings to be strongly determined by national public policy approaches concerned with families and children (Innocenti Research Centre, 2005, 2007, 2010). The primary dimension which seems beyond dispute is that nations that intervene in the operation of the market economy to provide families with the means (e.g., employment security and living wages, family benefits and entitlements, supports during periods of unemployment, disability, and illness) of living economically and socially secure lives - that is, the SDCH - are the ones whose children show better health and well-being outcomes (Esping-Andersen, 2002a). Canada is not one of these nations (Doherty \& Friendly, 2004; Friendly, 2009; Hertzman, 2000, 2008; Raphael, 2010c).

\section{The State of the Social Determinants of Canadian Children's Health}

Children's health is therefore integrally related to the health and well-being of their families (Engster \& Stensota, 2011; Esping-Andersen, 2002a). The most important SDCH therefore have much to do with their parents' living and working conditions (Campaign 2000, 2004; Innocenti Research Centre, 2007; Mikkonen \& Raphael, 2010). The most important of these is income which for most parents is a function of their employment and working conditions. For those parents unable to participate in the labour market, family income is determined by level of benefits and assistance provided by governmental programs. Important SDCH also include housing quality and food security which, while closely related to income, are shaped by specific public policies that address these areas (Bryant, 2009; Tarasuk, 2009). Government support of early child development through the provision of affordable childcare and early childhood education is also an important SDCH, as are the health and social services that are available (Friendly, 2009; McGibbon, 2009).

Finally, in Canada, one’s personal identity or social location (e.g., class, gender, race, Aboriginal, immigrant, or disability status, etc.) also play an important role in shaping access to the conditions necessary for health (Anderson, 2011). This has much to do with the unequal distribution of power and influence that comes to shape the distribution of economic and social resources - that is, the SDCH - important to health (Grabb, 2007; Raphael, 2011d). The next section presents what is known about the quality and distribution of four key clusters of SDCH: income and employment of their parents, food and housing security, early child development, and children's specific social locations.

\section{Income and Employment}

Income has a direct effect - through parents' and children’s living and working conditions - on children's health (Auger \& Alix, 2009; Lightman, Mitchell, \& Wilson, 2008; Raphael, 2010b). The most apparent demonstration of income's effects on children's health is the relationship between poverty and health outcomes (Beiser, Hou, Hyman, \& Tousignant, 2002; Engster \& Stensota, 2011; Raphael, 2011c; Singer, 2003). Children living in family poverty - defined as either absolute or relative - are more likely than other children to experience a whole range of physical, mental, and social health problems (Lightman et al., 2008; Raphael, 2010a; Raphael, 2011c; Wallis \& Kwok, 2008). The Innocenti Research Centre provides comparative poverty rates - using a relative definition of $<50 \%$ of the median family income - for wealthy developed nations (Innocenti Research Centre, 2013). 
International Journal of Child, Youth and Family Studies (2014) 5(2): 220-239

For the 2009-2010 period the poverty rate for children - representing the poverty rate of their families - was 14\% which gave Canada a ranking of 25th of 35 wealthy developed nations (Innocenti Research Centre, 2013). On the indicator of child poverty gap - the gap between the poverty line and the median income of those below the poverty line as a percentage of the poverty line - Canadian children are $22 \%$ below the poverty line. This gives Canada a ranking of 17th of 35 wealthy developed nations. These poverty rates for families with children have for the most part remained unchanged over the past 20 years. Since 14\% of Canadian families with children live in poverty, large numbers of Canadian children experience various forms of material and social deprivation that manifests in a variety of adverse health outcomes (Innocenti Research Centre, 2013).

A nation's poverty rate is determined in large part by how governments act to regulate employment and working conditions (Jackson, 2010). In Canada, there is little attempt by the State to regulate employment and working conditions (Tompa, Polanyi, \& Foley, 2009). The OECD calculates an employment protection index of rules and regulations that protect employment and provide benefits to temporary workers (Organisation for Economic Cooperation and Development, 2011d). Canada performs very poorly on this index, achieving a score that was ranked 26th of 28 nations. The OECD also provides data on the percentage of work identified as being low waged (Organisation for Economic Co-operation and Development, 2013). This index considers earning less than two-thirds of the median income as constituting low-wage employment. Even without data from the Nordic nations of Norway and Sweden which historically have levels below 5\%, Canada ranks 22nd of 22 OECD nations in having the highest proportion of men identified as low-wage workers at 21\%. Canada's percentage of lowpaid women workers (22\%) give it a ranking of 10th of 22 nations which is a reflection of nations such as Japan, Australia, Korea, Germany, and Great Britain, among others, having very high proportions of women working for low pay.

For those parents unable to work, levels of social assistance are the key factors determining income levels. The supports offered by Canadian governments are well below those provided by most other wealthy developed nations. The OECD publishes extensive statistics on social assistance spending amongst its members (Organisation for Economic Co-operation and Development, 2011b). Canada ranks 22nd of 39 members on social assistance payments, 23rd of 28 for unemployment benefits, 27th of 29 for services for people with disabilities, and 25th of 29 for general supports and benefits to families with children (Organisation for Economic Cooperation and Development, 2009a, 2009b). For those families with children dependent on such benefits, this places them well below the poverty line, however defined (National Council of Welfare, 2010; Organisation for Economic Co-operation and Development, 2011b; Organisation for Economic Co-operation and Development, 2009c; Raphael, 2011a).

\section{Food Security and Housing}

The ability to obtain food and housing is closely related to income and the distribution of income (Bryant, 2009; McIntyre \& Rondeau, 2009). Not surprisingly, families living in poverty are more likely to experience food insecurity and live in problematic housing situations.(Tarasuk, 2009). In addition, the extent of food insecurity and inadequate housing - important SDCH - are 
International Journal of Child, Youth and Family Studies (2014) 5(2): 220-239

also impacted by public policy in these specific areas (McIntyre \& Rondeau, 2009; Shapcott, 2009). Canada is one of few wealthy developed nations without a national housing strategy (Shapcott, 2009). It also has no food security strategy of note (McIntyre \& Rondeau, 2009).

Figures concerning the amount of food insecurity and inadequate housing in Canada are alarming. Close to $11 \%$ of Canadian families with children experience significant food insecurity (McIntyre \& Rondeau, 2009). The growing numbers of food bank users across Canada - of which $40 \%$ of them are children - is said to underestimate the percentage of families experiencing food insecurity. Similarly, the percentage of Canadians experiencing inadequate housing is also striking (Bryant, Raphael, Schrecker, \& Labonte, 2011). The Canada Mortgage and Housing Corporation estimates that $26 \%$ percent of urban families with children are in core housing need, either paying more than 30\% of their incomes on housing, living in crowded housing, or living in substandard housing (Canada Mortgage and Housing Corporation, 2012). Food insecurity and inadequate housing have been shown to be strongly related to adult health outcomes (Bryant, 2009; Tarasuk, 2009). There is little reason to doubt that these issues play a significant role in shaping the health of children as well.

\section{Early Child Development}

Canada is one of the lowest spenders on supports and benefits for early child development (Innocenti Research Centre, 2008; Organisation for Economic Co-operation and Development, 2011c). There is no national childcare program to speak of and comparative studies place Canada at the bottom of the heap in its support for families with children (Doherty \& Friendly, 2004). Programs that are available are targeted and there is little evidence of effectiveness in strengthening the SDCH and making their distribution more equitable (Raphael, 2010c).

In regard to access to regulated childcare - an important contributor to child well-being only $17 \%$ of Canadian families have access to regulated child care (Friendly \& Prentice, 2009). Even in Quebec where an extensive effort is underway to provide regulated high quality childcare, only $25 \%$ of families have access to it. The OECD published a report that rates Canada as last among 25 wealthy developed nations in meeting various early childhood development objectives (Doherty \& Friendly, 2004). Canada is also one of the lowest spenders on early childhood education, ranking 36th of 37 wealthy developed nations (Organisation for Economic Co-operation and Development, 2011b).

\section{Social Locations}

All these SDCH-related issues are closely related to adults' - and their children's - social location in Canadian society. Social location refers to aspects of one's personal identity such as class, race, gender, Aboriginal status, immigrant status, disability status, as well as other personal characteristics (Raphael, 2011d). In Canadian society, these characteristics are indicators of power and influence and are therefore related to access to economic and social resources that shape health status (Grabb, 2007). In Canada being of working class origin, a person of colour, female, Aboriginal, a recent immigrant, and/or having a disability is related to both the quality of the SDCH one is exposed to, as well as to the adverse health outcomes that result from such 
International Journal of Child, Youth and Family Studies (2014) 5(2): 220-239

exposures (Galabuzi, 2009; Jackson, 2010; Rioux, 2010; Smylie, 2009). Canadian children in these social locations are more likely to experience: (a) a reduced level of health-supporting $\mathrm{SDCH}$; and (b) adverse physical, mental, and social health outcomes.

It says much about Canadian society that so many social locations come first to be related to adverse living and working conditions and secondly to unfavourable health outcomes. The social inequality literature shows that these social locations are associated with differing living and working conditions as a result of these groups having less influence on the making of public policy by governmental authorities whose attention is more focused on the needs of the more powerful and wealthy (Grabb, 2007). These social locations are also important as Canadian governmental authorities do little to manage the inequality-producing aspects of the dominant institution in Canadian society - the market economy (Leys, 2001; Macarov, 2003; Saint-Arnaud \& Bernard, 2003). Means of balancing these differences in power and influence through governmental intervention in and management of the market economy in the areas of employment security, the setting of wages, and provision of family and child supports should be an important concern (Esping-Andersen, 2002a, 2002b).

\section{The Determinants of the Determinants}

It is becoming more apparent that simple explication of the importance of the SDCH has done little to improve their quality and make their distribution more equitable in Canada (Bryant et al., 2011; Collins \& Hayes, 2007; Hancock, 2011). Increasingly, attention is being paid to the importance of public policy in shaping the quality and distribution of the SDCH (Raphael, 2011a). In addition, analysis is focusing on how public policy within a nation is very much a function of the general organization of governmental decision-making. These differences have come to be known as a "worlds of welfare" analysis and, not surprisingly, Canada falls within the cluster which is the least likely to support the strengthening and more equitable distribution of the SDCH (Esping-Andersen, 1999; Saint-Arnaud \& Bernard, 2003). And even more enlightening has been analysis of how political organization and political values of governing authorities shape these general forms of the welfare state (Coburn, 2010; Navarro et al., 2004; Navarro et al., 2006). All of this work suggests that improving the quality and distribution of the SDCH requires careful political analysis of a range of issues that include public policy, political ideology, and public understandings of these issues.

\section{Public Policy}

Public policy is primarily concerned with whether a problem is recognized as being a societal rather than an individual problem. If the former, the solution is one that should be undertaken by society in the form of government activity as opposed to being left to the individual to solve (Briggs, 1961; Stone, 1988). Despite a long tradition of individualism in Western societies, it is becoming increasingly apparent that many of the problems that face us in the 21st century require communal solutions carried out under the authority of governments (Hofrichter, 2003; Raphael, 2003). With regard to SDCH, there is no shortage of areas that require such governmental intervention. 
International Journal of Child, Youth and Family Studies (2014) 5(2): 220-239

These public policy areas include issues of employment and working conditions, provision of benefits to families and individuals to provide important necessities such as food and housing, and support of early child development. If these issues are not considered as public problems and therefore not amenable to government action, then they are left to the other major sector of society, the normal operation of the economic system.

This is far from an acceptable solution, since despite what we have been led to believe by pro-business and conservative institutions and organizations, the economic system as it is constituted today in Canada and other Western countries is ill-suited to provide families with the means by which their children can experience high quality SDCH (Coburn, 2004, 2010; Hertzman \& Siddiqi, 2000; Leys, 2001; Macarov, 2003). The economic system itself says little about the provision of health promoting levels of education, health care, income and employment, food and housing, and if left to its own devices does little to improve the SDCH.

Differences between nations in providing quality and equitable distribution of SDCH are due to differences in intervening and managing many aspects of the economic system (Brady, 2009; Pontusson, 2005; Swank, 2005; Teeple, 2000). This is not only the case in the Social Democratic nations of Scandinavia but also among the Conservative nations of Continental Europe. This is a reflection of both groups of nations' long tradition of suspicion about the ability of the economic system to meet the most important needs of the citizenry (EspingAndersen, 1990). It is only in the Liberal nations such as Canada, the United Kingdom, the United States, and Australia that the belief is often stated that a well-functioning and profitable economic system will serve to meet the most important needs of the citizenry. Such a view is patently untrue. It should not be surprising then that nations that do intervene in the operation of the economic system are the ones that provide children and their families with the conditions necessary for health. This raises the issue of the concept of the welfare state and where Canada fits into its various forms.

\section{Welfare State Approach, Politics, and Political Ideology}

Esping-Andersen's distinction between Social Democratic, Conservative, and Liberal welfare states has much to do with the SDCH (Esping-Andersen, 1990, 1999). Figure 1 shows how the basic elements and characteristics of these differing forms of the welfare state have the potential to affect the SDCH and children's health itself (Saint-Arnaud \& Bernard, 2003). These differing forms of the welfare state have not come about by accident but have much to do with the ideology of governing authorities informed by the politics of governing parties. 
Figure 1. Ideological Variations in Forms of the Welfare State

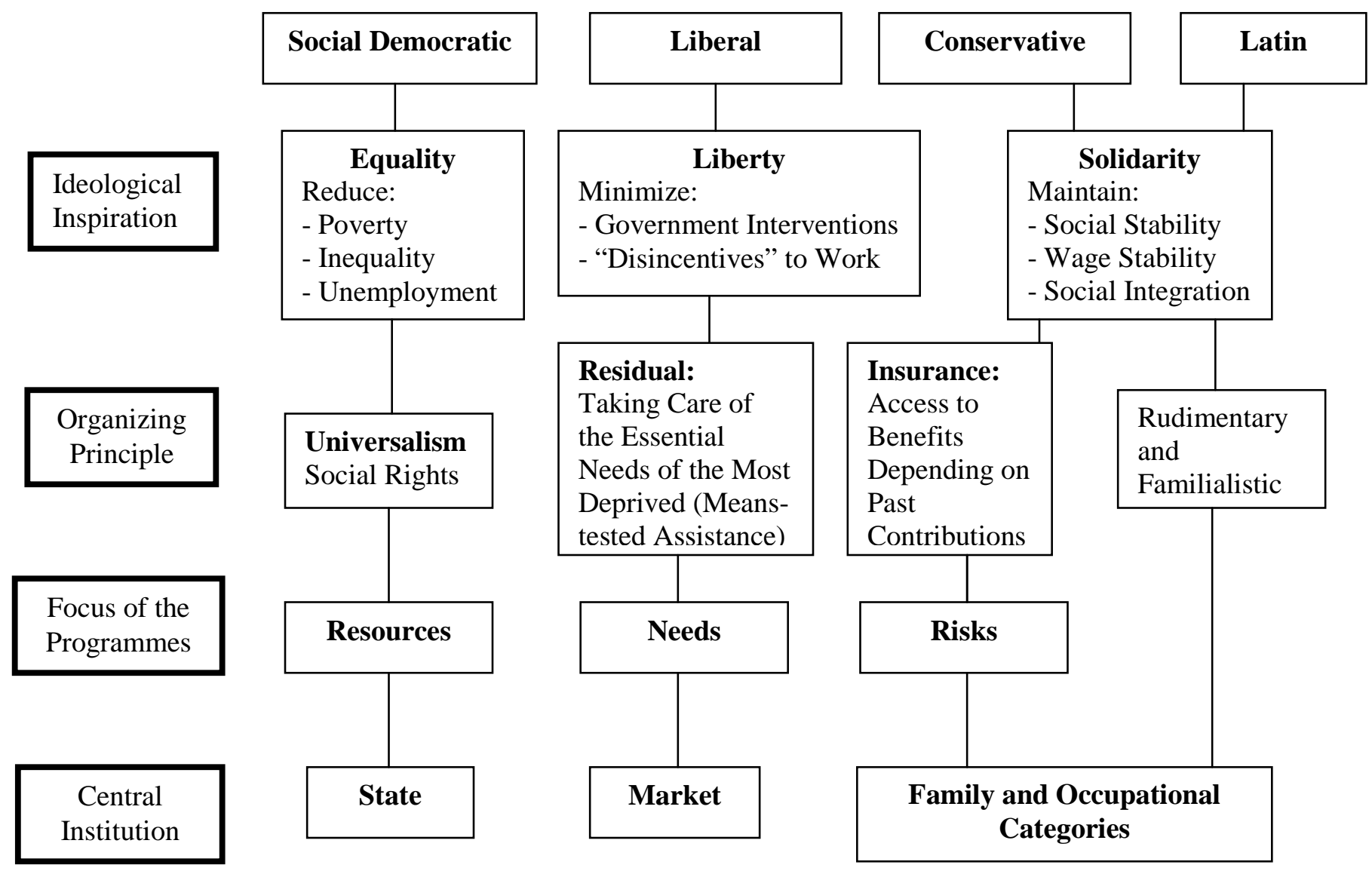

Source: Saint-Arnaud, S., \& Bernard, P. (2003). Convergence or resilience? A hierarchial cluster analysis of the welfare regimes in advanced countries. Current Sociology, 51(5), 499-527, Figure 2, p. 503. 
International Journal of Child, Youth and Family Studies (2014) 5(2): 220-239

The Social Democratic welfare state has been strongly influenced by the Social Democratic tradition (Esping-Andersen, 1985, 1990; Fosse, 2011, 2012). The Conservative welfare state is distinguished by governance of Christian Democratic parties that have traditionally maintained many aspects of social stratification, some degree of commodification of societal resources, and an important role for the Church (Esping-Andersen, 1990, 1999). Finally the Liberal welfare state is dominated by its governance by political parties that have been identified as being pro-business generally with resistance to intervene in the operation of the economic system (Esping-Andersen, 1990; Myles, 1998; Myles \& Quadagno, 2002).

Such an analysis suggests either changing the politics of those parties in power or electing parties of differing political persuasions that can be depended upon to implement the kinds of public policies shown to be so effective in improving the quality and distribution of the SDCH and promoting the health of children themselves. This requires recognition that ultimately issues related to the SDCH are political issues that require not only careful policy analysis but also recognition of the important role that politics, ideology, and values play in shaping the factors important to children’s health (Bryant, 2012; Raphael, 2012b).

\section{Acting to Strengthen the Social Determinants of Children's Health in Canada}

The situation of children in Canada is not helped by the fact that the State provides rather little in terms of universal entitlements outside of health care, libraries, and education from kindergarten through Grade 12. This is in marked contrast to many other wealthy developed nations where parents are routinely provided with State supports for having children through family allowances and the provision of childcare and housing supports.

Having identified these issues, the task is to identify what means can be implemented to improve the current situation. A wide variety of actions are possible. The important question is which approach will ultimately prove to be the most successful in shifting a society’s approach to the SDCH, thereby promoting children's health.

\section{Improve Services}

No one would dispute the importance of improving children's health and social services. Such services need to be responsive, effective, efficient, and geared to the particular needs of those who require them. Certainly, every attempt should be made to improve their quality (Haddad, 2011b).

\section{Change Behaviours}

There is also ongoing attention to changing the behaviours of children and their parents in the hope that this will improve health. These usually include issues of tobacco and alcohol use, diet, physical activity, and weight control. People's behaviours are strongly embedded however within those particular environments in which they live and work (Jarvis \& Wardle, 2003), and this is especially the case for children. All too frequently this leads to the simplistic approach by which people of particular social locations are identified as being particular targets for interventions to change their behaviour (Raphael, 2011b). Such an approach in itself can be 
International Journal of Child, Youth and Family Studies (2014) 5(2): 220-239

stigmatizing, ineffective, and do little to actually improve the living and working conditions that spawn health and other problems (Labonte \& Penfold, 1981).

\section{Strengthen Environments through Community Development Activities}

Community development approaches work on the assumption that if individuals and families come together to effect change they will be able to do so (Heritage \& Dooris, 2009; Park, 1993). Such a belief assumes that governing authorities are receptive to the ideas and wishes identified through such activities. Sadly in Canada, this has not recently been the case and it appears that governments are becoming more and more resistant to responding to the particular needs of individuals and communities. This suggests that it may be necessary to organize communities to not try to persuade governing authorities to effect change, but rather to undertake actions that will force government authorities - through fear of electoral defeat - to take actions to improve the SDCH and make their distribution more equitable (Bryant et al., 2011).

\section{Strengthen Environments by Building Healthy Public Policy}

All of the previous activities mentioned are certainly worthwhile. They suffer, however, from their inadequacy to shape the public policy that determines the living and working conditions of parents and their children. Moreover, public policy analysis is not part of the training that health professionals usually receive. It is not just those in the health sciences who lack public policy analysis skills. Most academic disciplines - psychology, sociology, education, medicine, nursing, and social work - have little to offer in their curricula regarding public policy analysis. In fact, it could be argued that the only academic discipline that takes the issue of public policy seriously is that of political science.

Nevertheless it is becoming increasingly apparent to the health community that public policy plays a crucial role in shaping not only the health care system but also the SDCH. What are the specific public policy areas that are of such importance? As mentioned earlier, primary ones are those concerned with the distribution of income and wealth, provision of supports and benefits, and generally any public policy that concerns itself with the health and well-being of children.

Not surprisingly, the Nordic countries have acted upon many public policy areas that in the end come to strengthen the quality and make more equitable the distribution of the SDCH (Innocenti Research Centre, 2007, 2008, 2010). A short list would include universal, affordable childcare, the provision of financial supports to families with children that allow for the achievement of food and housing security, the provision of employment training and support prior to training and if employment is lost (Olsen, 2002, 2010). The ability to organize a large proportion of the population into labour unions is also a powerful driver of SDCH-related public policy (Raphael, 2012b). 
International Journal of Child, Youth and Family Studies (2014) 5(2): 220-239

\section{Conclusions}

The literature on the SDCH is providing increasing evidence that the primary means of improving their quality and making the distribution more equitable is through public policy that provides parents with the economic and social security necessary for health. These public policy areas shape all the SDCH of early childhood development, income and wealth distribution, employment security and working conditions, food and housing security, and the provision of health and social services. This argument outlines a major role for the State - acting on behalf of the majority of citizens - in taking an active role in the provision of economic and social security for citizens. Without such government intervention, the economic system creates the social inequalities that shape the quality and distribution of the SDCH. In nations such as Canada where there is growing withdrawal of the State from involvement in these areas, we see evidence of either stagnating or declining health of children.

While all of us should do what we can to improve the SDCH, it seems to me that the key issue to be considered is whether those concerned with the health of children will begin the important debate of the role of the State in providing parents and their children with the economic and social security necessary for health. Those working in the health field can either accept or reject this analysis. What they cannot do is ignore it. 
International Journal of Child, Youth and Family Studies (2014) 5(2): 220-239

\section{References}

Anderson, E. (2011). Feminist epistemology and philosophy of science. Retrieved October 1, 2011, from http://plato.stanford.edu/archives/spr2011/entries/feminism-epistemology/

Auger, N., \& Alix, C. (2009). Income and health in Canada. In D. Raphael (Ed.), Social determinants of health: Canadian perspectives (2nd ed., pp. 61-74). Toronto: Canadian Scholars' Press.

Beiser, M., Hou, F., Hyman, I., \& Tousignant, M. (2002). Poverty, family process, and the mental health of immigrant children in Canada. American Journal of Public Health, 92(2), 220-227. http://dx.doi.org/10.2105/ajph.92.2.220

Brady, D. (2009). Rich democracies, poor people: How politics explain poverty. New York: Oxford University Press.

Briggs, A. (1961). The welfare state in historical perspective. European Journal of Sociology, 2, 251-259. http://dx.doi.org/10.1017/s0003975600000412

Bryant, T. (2009). Housing and health: More than bricks and mortar. In D. Raphael (Ed.), Social determinants of health: Canadian perspectives (2nd ed., pp. 235-249). Toronto: Canadian Scholars' Press.

Bryant, T. (2012). Applying the lessons from international experiences. In D. Raphael (Ed.), Tackling health inequalities: Lessons from international experiences (Chapter 10). Toronto: Canadian Scholars' Press Incorporated.

Bryant, T., Raphael, D., Schrecker, T., \& Labonte, R. (2011). Canada: A land of missed opportunity for addressing the social determinants of health. Health Policy, 101(1), 4458. http://dx.doi.org/10.1016/j.healthpol.2010.08.022

Butler-Jones, D. (2008). Report on the state of public health in Canada 2008: Addressing health inequalities. Ottawa: Public Health Agency of Canada.

Campaign 2000. (2004). Moving forward for Ontario's children and families: 2004 Report Card on child poverty in Ontario. Toronto: Campaign 2000.

Canada Mortgage and Housing Corporation. (2012). Recent Trends in housing affordability and core housing need. Ottawa: Author. Retrieved October 20, 2013, from http://www.cmhc.ca/en/corp/about/cahoob/upload/Chapter_5_EN_w_dec11.pdf

Coburn, D. (2004). Beyond the income inequality hypothesis: Globalization, neo-liberalism, and health inequalities. Social Science \& Medicine, 58, 41-56. http://dx.doi.org/10.1016/s0277-9536(03)00159-x

Coburn, D. (2010). Health and health care: A political economy perspective. In T. Bryant, D. Raphael, \& M. Rioux (Eds.), Staying alive: Critical perspectives on health, illness, and health care. (2nd ed., pp. 65-92). Toronto: Canadian Scholars' Press. 
International Journal of Child, Youth and Family Studies (2014) 5(2): 220-239

Collins, P., \& Hayes, M. (2007). Twenty years since Ottawa and Epp: Researchers' reflections on challenges, gains, and future prospects for reducing health inequities in Canada. Health Promotion International, 22(4), 337-345. http://dx.doi.org/10.1093/heapro/dam031

Doherty, G., \& Friendly, M. (2004). OECD thematic review of early childhood education and care. Ottawa: Government of Canada.

Engster, D., \& Stensota, H. O. (2011). Do family policy regimes matter for children's wellbeing? Social Politics: International Studies in Gender, State \& Society, 18(1), 82-124. http://dx.doi.org/10.1093/sp/jxr006

Esping-Andersen, G. (1985). Politics against markets: The social democratic road to power. Princeton, NJ: Princeton University Press.

Esping-Andersen, G. (1990). The three worlds of welfare capitalism. Princeton, NJ: Princeton University Press.

Esping-Andersen, G. (1999). Social foundations of post-industrial economies. New York: Oxford University Press. http://dx.doi.org/10.1093/0198742002.001.0001

Esping-Andersen, G. (2002a). A child-centred social investment strategy. In G. Esping-Andersen (Ed.), Why we need a new welfare state (pp. 26-67). Oxford, UK: Oxford University Press. http://dx.doi.org/10.1093/0199256438.003.0002

Esping-Andersen, G. (2002b). Towards the good society, once again? In G. Esping-Andersen (Ed.), Why we need a new welfare state (pp. 1-25). Oxford, UK: Oxford University Press. http://dx.doi.org/10.1093/0199256438.003.0001

Fosse, E. (2011). Different welfare states-different policies? An analysis of the substance of national health promotion policies in three European countries. International Journal of Health Services, 41(2), 255-272. http://dx.doi.org/10.2190/hs.41.2.e

Fosse, E. (2012). Norwegian experiences. In D. Raphael (Ed.), Tackling health inequalities: Lessons from international experience (pp. 185-208). Toronto: Canadian Scholars' Press.

Friendly, M. (2009). Early childhood education and care as a social determinant of health. In D. Raphael (Ed.), Social determinants of health: Canadian perspectives (2nd ed., pp. 128142). Toronto: Canadian Scholars' Press.

Friendly, M., \& Prentice, S. (2009). Childcare. Halifax, NS: Fernwood Publishing.

Galabuzi, G. E. (2009). Social exclusion. In D. Raphael (Ed.), Social determinants of health: Canadian perspectives (2nd ed., pp. 252-268). Toronto: Canadian Scholars' Press.

Grabb, E. (2007). Theories of social inequality (5th ed.). Toronto: Harcourt Canada.

Haddad, M. J. (2010). Child health in Canada: Social determinants. Healthcare Quarterly, 14(1). 
International Journal of Child, Youth and Family Studies (2014) 5(2): 220-239

Haddad, M. J. (2011a). Child health in Canada: Child and youth mental health. Healthcare Quarterly, 14(2).

Haddad, M. J. (2011b). Child health in Canada: Health system performance. Healthcare Quarterly, 14(3).

Haddad, M. J. (2012). Child health in Canada: Investing in children's health. Healthcare Quarterly, 15(4).

Hancock, T. (2011). Health promotion in Canada: 25 years of unfulfilled promise. Health Promotion International, 26(suppl 2), ii263-ii267.http://x.doi.org/10.1093/heapro/dar061

Heritage, Z., \& Dooris, M. (2009). Community participation and empowerment in healthy cities. Health Promotion International, 24(suppl 1), i45-i55. http://dx.doi.org/10.1093/heapro/dap054

Hertzman, C. (2000). The case for an early childhood development strategy. Isuma (Autumn), $11-18$.

Hertzman, C. (2008). The 18-month well-baby visit: A commentary. Paediatrics and Child Health, 13, 843-844.

Hertzman, C., \& Power, C. (2003). Health and human development: Understandings from lifecourse research. Developmental Neuropsychology, 24(2\&3), 719-744. http://dx.doi.org/10.1207/s15326942dn242\&3_10

Hertzman, C., \& Siddiqi, A. (2000). Health and rapid economic change in the late twentieth century. Social Science \& Medicine, 51(6), 809-819. http://dx.doi.org/10.1016/s0277-9536(00)00062-9

Hofrichter, R. (2003). The politics of health inequities: Contested terrain. In Health and Social Justice: A Reader on Ideology, and Inequity in the Distribution of Disease (pp. 1-56). San Francisco: Jossey Bass.

Innocenti Research Centre. (2001a). A league table of child deaths by injury in rich nations. Florence: Innocenti Research Centre.

Innocenti Research Centre. (2001b). A league table of teenage births in rich nations. Florence: Innocenti Research Centre.

Innocenti Research Centre. (2003). A league table of child maltreatment deaths in rich nations. Florence: Innocenti Research Centre.

Innocenti Research Centre. (2005). Child poverty in rich nations, 2005. Report card no. 6. Florence: Innocenti Research Centre.

Innocenti Research Centre. (2007). An overview of child well-being in rich countries: A comprehensive assessment of the lives and well-being of children and adolescents in the economically advanced nations. Florence, Italy: Innocenti Research Centre. 
International Journal of Child, Youth and Family Studies (2014) 5(2): 220-239

Innocenti Research Centre. (2008). The child care transition: A league table of early childhood education and care in economically advanced countries. Florence: Author.

Innocenti Research Centre. (2010). The children left behind: A league table of inequality in child well-being in the world's rich countries. Florence: Innocenti Research Centre.

Innocenti Research Centre. (2013). Child well-being in rich countries: A comparative overview. Florence: Innocenti Research Centre.

Irwin, K. G., Siddiqui, A., \& Hertzman, C. (2007). Early child development: A powerful equalizer. Geneva: World Health Organization.

Jackson, A. (2010). Work and labour in Canada: Critical issues (2nd ed.). Toronto: Canadian Scholars' Press.

Jarvis, M. J., \& Wardle, J. (2003). Social patterning of individual health behaviours: The case of cigarette smoking. In M. G. Marmot \& R. G. Wilkinson (Eds.), Social determinants of health (2nd ed., pp. 224-237). Oxford, UK: Oxford University Press. http://dx.doi.org/10.1093/acprof:oso/9780198565895.003.11

Kuh, D., Ben Shlomo, Y., \& Susser, E. (Eds.). (2004). A life course approach to chronic disease epidemiology (2nd ed.). Oxford, UK: Oxford University Press.

Labonte, R., \& Penfold, S. (1981). Canadian perspectives in health promotion: A critique. Health Education, 19, 4-9.

Leys, C. (2001). Market-driven politics. London, UK: Verso.

Lightman, E., Mitchell, A., \& Wilson, B. (2008). Poverty is making us sick: A comprehensive survey of income and health in Canada. Toronto: Wellesley Institute.

Macarov, D. (2003). What the market does to people: Privatization, globalization, and poverty. Atlanta, GA: Clarity Press.

McGibbon, E. (2009). Health and health care: A human rights perspective. In D. Raphael (Ed.), Social determinants of health: Canadian perspectives (2nd ed., pp. 318-335). Toronto: Canadian Scholars' Press.

McIntyre, L., \& Rondeau, K. (2009). Food insecurity in Canada. In D. Raphael (Ed.), Social determinants of health: Canadian perspectives (2nd ed., pp. 188-204). Toronto: Canadian Scholars' Press.

Mikkonen, J., \& Raphael, D. (2010). Social determinants of health: The Canadian facts. Retrieved November 1, 2010, from http:/thecanadianfact.org

Myles, J. (1998). How to design a "Liberal" welfare state: A comparison of Canada and the United States. Social Policy and Administration, 32(4), 341-364. 
International Journal of Child, Youth and Family Studies (2014) 5(2): 220-239

Myles, J., \& Quadagno. (2002). Political theories of the welfare state. Social Service Review, 76(1), 34-57.

National Council of Welfare. (2010). Welfare incomes 2009. Ottawa: National Council of Welfare.

Navarro, V., Borrell, C., Benach, J., Muntaner, C., Quiroga, A., Rodrigues-Sanz, M., et al. (2004). The importance of the political and the social in explaining mortality differentials among the countries of the OECD, 1950-1998. In V. Navarro (Ed.), The political and social contexts of health (pp. 11-86). Amityville, NY: Baywood Press.

http://dx.doi.org/10.2190/r7ge-8dwk-yy6c-183u

Navarro, V., Muntaner, C., Borrell, C., Benach, J., Quiroga, A., Rodríguez-Sanz, M., et al. (2006). Politics and health outcomes. The Lancet, 368, 1033-1037. http://dx.doi.org/10.1016/s0140-6736(06)69341-0

Olsen, G. (2002). The politics of the welfare state. Don Mills, ON: Oxford University Press.

Olsen, G. (2010). Power and inequality: A comparative introduction. Toronto: Oxford University Press.

Organisation for Economic Co-operation and Development. (2009a). Generosity of unemployment benefits. Paris: Author. Retrieved October 20, 2013, from http://dx.doi.org/10.1787/706364844714.

Organisation for Economic Co-operation and Development. (2009b). Net incomes of social assistance recipients in relation to alternative poverty lines, 2007. Paris: Author. Retrieved October 22, 2013, from http://dx.doi.org/10.1787/706265650677

Organisation for Economic Co-operation and Development. (2009c). Society at a glance: Social indicators 2009. Paris: Organisation for Economic Co-operation and Development.

Organisation for Economic Co-operation and Development. (2011a). OECD health data 2011 Frequently requested data. Paris: Author. Retrieved December 15, 2011, from http://www.oecd.org/document/16/0,3343,en_2649_34631_2085200_1_1_1_1,00.html

Organisation for Economic Co-operation and Development. (2011b). Social expenditure database (SOCX). Paris: Author. Retrieved February 25, 2012, from http://www.oecd.org/document/9/0,3746,en_2649_34637_38141385_1_1_1_1,00.html

Organisation for Economic Co-operation and Development. (2011c). Society at a glance 2011, OECD social indicators. Paris: Organisation for Economic Co-operation and Development.

Organisation for Economic Co-operation and Development. (2011d). Strictness of employment protection. Paris: Author. Retrieved January 31, 2012, from http://stats.oecd.org/Index.aspx?DataSetCode=EPL_OV 
International Journal of Child, Youth and Family Studies (2014) 5(2): 220-239

Organisation for Economic Co-operation and Development. (2013). Employment policies and data, Online OECD Employment Database. Paris: Author. Retrieved October 22, 2013, from http://www.oecd.org/employment/emp/onlineoecdemploymentdatabase.htm.

Park, P. (1993). What is participatory research? A theoretical and methodological perspective. In P. Park, M. Brydon-Miller, B. Hall, \& T. Jackson (Eds.), Voices of change: Participatory research in the United States and Canada (pp. 1-19). Toronto: Ontario Institute for Studies in Education Press.

Pontusson, J. (2005). Inequality and prosperity: Social Europe versus liberal America. Ithaca, NY: Cornell University Press.

Raphael, D. (2003). Towards the future: Policy and community actions to promote population health. In R. Hofrichter (Ed.), Health and social justice: A reader on politics, ideology, and inequity in the distribution of disease (pp. 453-468). San Francisco: Jossey Bass.

Raphael, D. (2010a). The health of Canada's children. Part I. Canadian children's health in comparative perspective. Paediatrics and Child Health, 15(1), 23-29.

Raphael, D. (2010b). The health of Canada's children. Part II. Health mechanisms and pathways. Paediatrics and Child Health, 15(2), 71-76.

Raphael, D. (2010c). The health of Canada's children. Part III. Public policy and the social determinants of children's health. Paediatrics and Child Health, 15(3), 143-149.

Raphael, D. (2010d). The health of Canada's children. Part IV. Towards the future. Paediatrics and Child Health, 15(4), 199-204.

Raphael, D. (2011a). Canadian public policy and poverty in international perspective. In D. Raphael (Ed.), Poverty in Canada: Implications for health and quality of life (pp. 374405). Toronto: Canadian Scholars' Press.

Raphael, D. (2011b). A discourse analysis of the social determinants of health. Critical Public Health, 21(2), 221-236.

Raphael, D. (2011c). Poverty in Canada: Implications for health and quality of life (2nd ed.). Toronto: Canadian Scholars' Press.

Raphael, D. (2011d). Who is poor in Canada? In D. Raphael (Ed.), Poverty in Canada: Implications for health and quality of life, (2nd ed., pp. 62-89). Toronto: Canadian Scholars' Press.

Raphael, D. (2012a). Canadian experiences. In D. Raphael (Ed.), Tackling health inequalities: Lessons from international experiences. Toronto: Canadian Scholars' Press. 
International Journal of Child, Youth and Family Studies (2014) 5(2): 220-239

Raphael, D. (Ed.). (2012b). Tackling inequalities in health: Lessons from international experiences. Toronto: Canadian Scholars' Press Incorporated.

Rioux, M. (2010). The right to health: Human rights approaches to health. In D. Raphael, T. Bryant, \& M. Rioux (Eds.), Staying alive: Critical perspectives on health, illness, and health care (Chapter 4). Toronto: Canadian Scholars' Press, Inc.

Robert Wood Johnson Foundation. (2008). Overcoming obstacles to health. Princeton, NJ: Robert Wood Johnson Foundation.

Saint-Arnaud, S., \& Bernard, P. (2003). Convergence or resilience? A hierarchial cluster analysis of the welfare regimes in advanced countries. Current Sociology, 51(5), 499-527. http://dx.doi.org/10.1177/00113921030515004

Shapcott, M. (2009). Housing. In D. Raphael (Ed.), Social determinants of health: Canadian perspectives (2nd ed., pp. 221-234). Toronto: Canadian Scholars' Press.

Singer, R. (2003). The impact of poverty on the health of children and youth. Toronto: Campaign 2000.

Smylie, J. (2009). The health of aboriginal people. In D. Raphael (Ed.), Social determinants of health: Canadian perspectives (2nd ed., pp. 280-301). Toronto: Canadian Scholars' Press.

Stone, D. (1988). Policy paradox and political reason. Glenview, IL: Scott, Foresman.

Swank, D. (2005). Globalisation, domestic politics, and welfare state retrenchment in capitalist democracies. Social Policy and Society, 4(2), 183-195. http://dx.doi.org/10.1017/s1474746404002337

Tarasuk, V. (2009). Food insecurity and health. In D. Raphael (Ed.), Social determinants of health: Canadian perspectives (2nd ed., pp. 205-220). Toronto: Canadian Scholars' Press.

Teeple, G. (2000). Globalization and the decline of social reform: Into the twenty first century. Aurora, ON: Garamond Press. http://dx.doi.org/10.5860/choice.38-3964

Tompa, E., Polanyi, M., \& Foley, M. (2009). Labour market flexibility and worker insecurity. In D. Raphael (Ed.), Social determinants of health: Canadian perspectives (2nd ed., pp. 8898). Toronto: Canadian Scholars' Press.

UNICEF Canada. (2013). Stuck in the middle. Toronto: UNICEF Canada.

Wallis, M., \& Kwok, S. (Eds.). (2008). Daily struggles: The deepening racialization and feminization of poverty in Canada. Toronto: Canadian Scholars' Press. 